\title{
Balancing the management control package of small, rapidly growing firms in turbulent environments
}

\author{
Anders Nilsson \\ Department of Business Administration and Social Science, \\ Accounting and Control, \\ Luleå University of Technology, \\ SE-97187 Luleå, Sweden \\ E-mail: L.E.Anders.Nilsson@1tu.se
}

\begin{abstract}
The thesis of this paper is that the management control package of small rapidly growing firms in turbulent environments needs to be based on a dynamic conception of balance. While many contemporary management control frameworks endorse balance as a guiding principle for management control, its specific features receive little attention and implicit conceptions are static. This paper first characterises the balance of a control package in terms of situational requirements on component selection, component weight, relations and coherence. The paper then examines the consistency between balance in contemporary management control frameworks and implications for balance derived from firm attributes. The conclusions suggest that by considering balance as a state and as an act, acknowledging requirements of balance and imbalance, and recognising situational and temporal dimensions of balance, we may advance the boundaries of management control research.
\end{abstract}

Keywords: balance; dynamic; entrepreneurship; environmental turbulence; imbalance; management control package; rapid growth; situational requirements; small firm attributes.

Reference to this paper should be made as follows: Nilsson, A. (2010) 'Balancing the management control package of small, rapidly growing firms in turbulent environments', Int. J. Entrepreneurship and Small Business, Vol. 11, No. 1, pp.3-24.

Biographical notes: Anders Nilsson is an Associate Professor of Accounting and Control at Luleå University of Technology, Sweden. His research interests include management control, information use and growth in small and medium-sized firms. His publications have appeared in journals including Journal of Enterprising Culture, Nordiske Organisasjonsstudier, Systems Practice, The Southern Business \& Economic Journal and Qualitative Research in Organisations and Management: an International Journal.

\section{Introduction}

At first glance, it would seem that there is good fit between the notion of a management control package (Otley, 1980) based on a set of components, and the realities of many small firms, which rely extensively on other control mechanisms than formal management accounting information (Nayak and Greenfield, 1994; Perren and Grant, 
2000). For such a package to be truly integrative, it is logical to expect the constituting components to be in balance, enabling the package as a whole to contribute to overall goal attainment.

When small firms grow rapidly, however, they experience numerous tensions (e.g., Moores and Yuen, 2001; Davila, 2005) and growing pains (Flamholtz and Randle, 2000) that trigger questions about what it might mean to balance the management control package in this context. The concept of balance occurs frequently in the literature (e.g., Frow et al., 2005; Desouza and Awuzu, 2006; Morris et al., 2006), but we know little about the specific characteristics of balance in different circumstances (Cardinal et al., 2004). For example, while balance is a notable theme in the literature on 'new' management accounting techniques (Lynch and Cross, 1991; Kaplan and Norton, 1992; Simons, 1995; see also Ewing and Samuelsson, 1998), the implicit practice of equating it with a desirable state may be misleading in a turbulent environment.

The paper argues that we need a rich and dynamic conception of balance as a basis for future empirical research on the management control package of small, rapidly growing firms in turbulent environments. Understanding the relationships between situational requirements, the structural composition of the control package, and its evolution over time, are pivotal questions for theory development in our field.

The structure of the remainder of the paper is as follows. In its conceptual points of departure, the paper introduces the characteristics of a management control package (Otley, 1980) and outlines four generic, situational, features of balance on which the paper relies. In the next section, the paper reviews the attributes of small firms, rapid growth and environmental turbulence, deriving implications of these particular situational requirements for the concept of balance. Thereafter, the paper examines the balanced scorecard ${ }^{1}$ [Kaplan and Norton (1992), Simon's (1995) levers of control and Otley's (1999) performance management framework, as three contemporary management control frameworks endorsing balance as a guiding principle $\left.{ }^{2}\right]$. These examinations centre on how the frameworks consider the notion of balance and on the consistency between the frameworks in this respect and implications for balance derived from firm attributes. In its concluding section, the paper provides a tentative conception of balance, which

1 incorporates balance as a state and as an act

2 acknowledges requirements of balance and imbalance

3 recognises situational and temporal dimensions of balance.

The intent is to stimulate future empirical research to advance the boundaries of control.

\section{Conceptual points of departure}

\subsection{Management control package}

Cybernetics (e.g., Beer, 1966) and management by exception (Anthony, 1965) represent influential intellectual foundations of management control. According to this line of reasoning, objectives are determined and subsequently used as indicators, to determine whether the organisation is performing according to plan. These operations depend on a 
formal management control system, a rational machine with interrelated parts, which aids in the provision of feedback. It is widely held that the cybernetic view of management control is well suited for the promotion of efficiency in stable conditions (Burns and Stalker, 1961; Brownell, 1987). As the subsequent literature review will demonstrate, the conditions for small, rapidly growing firms in turbulent environments are hardly stable (e.g., Covin and Slevin, 1989; Merz and Sauber, 1995) and control has informal features related to social interaction and ideology, orchestrated by the owner-manager (e.g., Perren and Grant, 2000; Collier, 2005).

This paper considers management control in terms of a comprehensive package (Otley, 1980) based on a mix of formal and social components for measuring, controlling and managing strategy implementation and achieving overall objectives (Ferreira and Otley, 2005). Thus, it refers to devices or systems for ensuring that the behaviours and decisions of firm employees are consistent with the organisation's objectives and strategies [Merchant and Van der Stede, (2007), p.5]. This paper refers to these devices and systems as components of the control package.

The formal components of the package constitute its officially declared and documented features, whereas its social components concern cultural values, beliefs and traditions cultivated through social interaction (e.g., Ouchi, 1979; Alvesson and Kärreman, 2004) and self-control exercised by individuals (Jönsson, 1992; Kirsch et al., 2002). The formal components often depict authority to make decisions and accountability with respect to organisational levels (Anthony, 1965). Centrally formulated rules to control behaviour and goals to enable output comparisons are key ingredients (Ouchi, 1979; Boland, 1979). The social components rely on lateral flows of information and communication to enable participative decision-making and empowerment ${ }^{3}$ (e.g., Otley et al., 1995; Dent, 1996; see also Vaivio, 2004). The formal and social components may be interrelated in different ways. Informal relationships serve to humanise and socialise the experience of work and leads to ties and loyalties that can facilitate effectiveness, although they are a source of schisms and conflicts for which the formal helps to compensate (Roberts, 1996). Informal ideas and norms may be formalised (Barker, 1993); the social may reinforce the formal (Ferner, 2000) and vice versa (Alvesson and Kärreman, 2004). If the formal and the social are incongruent, this creates imbalanced conditions, or tensions (Argyris, 1977, 1996; Norris and O’Dwyer, 2004). The weight of components and the connections between them can also shift over time (Kirsch et al., 2002; Cardinal et al., 2004).

From a contingency theory point of view, it would seem reasonable to expect a vertical orientation to be important in mechanistic organisations (Burns and Stalker, 1961) where the transformation process has programmable features and output measures can be subject to ex-post evaluations based on standards (Simon, 1960; Ouchi, 1979). A social orientation should be important for organic organisations and craft and research technologies (Daft and Macintosh, 1981), where situations encountered are unique and require experiential learning (Kolb, 1984) and socialisation for clan- and self-control (e.g., Jönsson, 1992). Contingency field studies in specific settings however indicate that combinations of controls are used simultaneously (Dent, 1987; Simons, 1990; Chapman, 1998). The extent to which the formal and social aspects can be congruent is receiving increasing interest (e.g., Roberts, 1991; Munro and Mouritsen, 1996; Llewellyn and Northcott, 2005). Evidence suggests that organisations that are not purely communal or bureaucratic need to balance these components (e.g., Lindkvist and Llewellyn, 2003). 


\subsection{On the notion of balance}

The concept of balance can be defined in numerous ways, and it is being used in several different contexts. Conceptually, balance often refers to a point between two opposite forces, which is preferable to exclusive reliance on either one. With certain variations in its meaning, the concept is used in contexts including biomechanics (in relation to maintaining the centre of gravity of a body), mechanics (in relation to engine vibrations) and the analysis of physical systems (for example concerning the design of chemical reactors and pollution dispersion models). As the very purpose of this paper is to explore the concept of balance and to begin to develop this concept as a basis for management control research in the context of small, rapidly growing firms in turbulent environments, the present section does not provide a precise definition of this concept. It is however important to emphasise that for the purposes of this paper, the notion of balance is not to be confused with the notion of equilibrium used by economists. The notion of a general equilibrium implies the assumption that the operation of economic forces is constrained by exogenous variables which are given from the outside and stable over time (e.g., Kaldor, 1972). Instead, this paper is focused on the configuration (Miller and Friesen, 1984) of the control package (Otley, 1980), which is socially constructed by decision-makers in small, rapidly growing firms that operate under turbulent conditions.

In the management control literature, there is an often-implicit view of balance as a desirable state of harmony or congruence, accomplished by means of a combination (Bradach and Eccles, 1989) of various components or dimensions which fits a particular situation (e.g., Simons, 1995; Ewing and Samuelsson, 1998). Although the contingency theory literature views firms as adaptive to change (e.g., Dent, 1987; Chapman, 1998), such adaptation takes place to reach a desirable state of balance, in response to situational changes. Cardinal et al. (2004) make this perspective explicit when they define balance as: '.. a state of harmonious use of multiple control dimensions, where the harmony of any such configuration relies on specific situational requirements and depends on achieving isomorphism with external and internal requirements' [Cardinal et al., (2004), p.412]. The relationships between components may be antithetical, orthogonal or synergistic (Sutcliffe et al., 2000). According to the predominant antithetical perspective, balance is viewed as a zero-sum game where increased weight on one component implies a reduction of emphasis on another (e.g., March, 1988; Osborn, 1998). The orthogonal perspective assumes dimensions independent, and depends on slack resources so that attention to one component does not come at the expense of another (e.g., Daft, 1982). The synergistic perspective treats different components as mutually supportive, where the challenge is to generate insight into the interdependencies. Cardinal et al. (2004) propose that the synergistic perspective fits well with fast-moving, complex situations such as those of small, rapidly growing firms in turbulent environments (e.g., Hambrick and Crozier, 1985; Fombrun and Wally, 1989; Moores and Yuen, 2001; Davila, 2005). In consideration of the conceptual points of departure in Subsections 2.1 and 2.2, this paper proposes to examine balance using the following generic features, where situational requirements determine suitability and adequacy (see also Figure 1):

- the mix of components included in the control package

- the distribution of weight allowed for the different components in the package

- the connections between components in the package

- the coherence in orientation between components in the package 
Figure 1 An example of generic balance features: components (inner circles), weight (size of inner circles), relations (connections) and coherence (inside arrows) of the control package (outer circle) in relation to situational requirements (outside arrows)

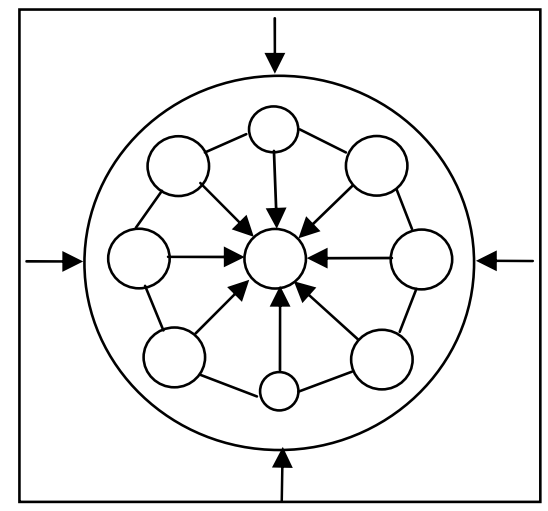

As the situational requirements of primary interest in the present paper are those of small, rapidly growing firms in turbulent environments, the next section reviews the attributes of such firms and derives implications thereof for the concept of balance.

\section{Small, rapidly growing firms in turbulent environments}

\subsection{Attributes of small firms}

The attributes of small firms vary with respect to matters such as industry type (Buick et al., 1998; Human and Provan, 1996) and company age (Feindt et al., 2002). As noted by Street and Cameron (2007), definitions may be structural and based on the number of employees or functional divisions (Vinten, 1999; Kohn, 1997). They may also be performance-related, based on annual revenues or depth of the product line (Yap et al., 1994; Calof, 1993; Evans, 1999; Dana, 1998). Consistent with Street and Cameron (2007) this paper considers small business as a relative term, that typically relates to an independently owned and operated firm which has fewer resources than others in its industry (see also Alvarez and Barney, 2002).

Small businesses may be financially vulnerable (Peel et al., 2000) because their revenue stream is dependent on a thin customer base. In firms that are owned and operated independently, the owners are residual claimants of their own managerial performance and can rely on self-monitoring (e.g., Yu, 2001). Decision making is typically concentrated with the owner-manager or to a small team possibly consisting of family members, who tend to act primarily on the basis of intuition and personal experience (Pearson et al., 1990; Davig and Brown, 1992) and control operations informally by interacting closely with employees (e.g., Ekanem and Smallbone, 2007). Human resources are by definition few, and strategic choices about the future of the firms depend on the vision and beliefs of the owner-managers (Sexton and VanAuken, 1982; $\mathrm{Yu}, 2001)$. The ability of entrepreneurs to process unstructured information usefully in an intuitive way is a distinctive intangible asset of small firms, often led by entrepreneurial founders (e.g., Bird, 1992; Feeser and Willard, 1989; Yu, 2001). 
It is well established that formal accounting controls often are instrumentally simplistic in small firms (e.g., Nayak and Greenfield, 1994; Reid and Smith, 2000). Control is highly informal and exercised interactively in dialogue with operations (e.g., Ekanem and Smallbone, 2007). For example, Häckner and Nilsson (1999) use the well-established ideas about the relationship between decision making and uncertainty developed by Simon (1960) and Thompson (1967) and elaborated on by Earl and Hopwood (1980) and Burchell et al. (1980), to study the use of accounting information systems in $\mathrm{SMEs}^{4}$. Their results show a positive relationship between formal models for product costing and profitability, also suggesting that firms with less instrumentally elaborate accounting controls use their experience from similar situations as a judgmental basis in situations where knowledge about causation is poor. High levels of trust and mutual accountability can also reduce dependency on formal controls ${ }^{5}$ (Jönsson, 1996). The formal controls are relatively insignificant when operations concern a narrow product line, and customer relations require interaction only with a small number of key-customers (Williamson, 1970; Galbraith, 1977). In such conditions, small firm competencies are mainly oriented towards sales and technical production aspects (Pratten, 1991) rather than to formal control, organisation and customer service. As the organisational complexity of small firms is low they are able to operate using a relatively simple organisation structure, which may help them be more flexible (Fiegenbaum and Karnani, 1991; Power and Reid, 2005) and speedy in response to environmental changes than large firms (Hitt and Ireland, 1985). The same is true about their capital structure, which implies that there are fewer irreversible investments and sunk costs that may hamper adaptations ( $\mathrm{Yu}, 2001)$. On the other hand, if resources are severely limited, the range of strategic options may decrease and make it difficult to adapt strategies in response to environmental changes (Pelham, 1999). One important means of compensating for in-house resource limitations in small firms is to build external relationships through formal and informal business networks and markets (e.g., Street and Cameron, 2007). Research suggests that small firms are more likely to form cooperative arrangements than larger ones (Shan, 1990).

For small firms that are young, survival chances are especially slim. Stinchcombe (1965) argues that new organisations suffer a liability of newness, facing a greater risk of failure than older organisations due to their dependence on the cooperation of strangers, their low levels of legitimacy and inability to compete with established organisations. Empirical evidence supports this thesis (e.g., Freeman et al., 1983) while indicating that a liability of smallness itself may be an important attribute. Small new firms may suffer from a lesser pool of financial resources than large new firms; they may face greater difficulties in raising more capital, have less favourable tax conditions and be in a more difficult position to recruit qualified labour (Brüdel et al., 1992). The liabilities of newness and smallness indicate the desirability and simultaneous difficulty of achieving growth in order to survive (Gilbert et al., 2006).

The attributes of small firms have implications for the concept of balance. With respect to the mix of components in the control package, the owner-manager needs to sense informally that operations are 'under control'. On the other hand, the package may require formal components to satisfy external parties such as banks and auditors, although the weight of informal components will exceed that of its formal counterparts. Such formal and social components are thus not necessarily coherent, even if they may be 
interconnected. Firm ideology is likely to be cultivated in social interaction. In addition, the control package may need to be oriented in a way that allows for horizontal resource acquisition through networks.

\subsection{Attributes of rapid growth}

Founding entrepreneurs of rapidly growing firms often have a college education; an entrepreneurial 'story' (motivation to become entrepreneur) and prior industry experience (Barringer et al., 2005). Such firms have a commitment to rapid growth, a state of obligation whereby individuals are bridged to one another (Hambrick et al., 1993; Stone and Brush, 1996). As noted by Gilbert et al. (2006), the attributes of rapidly growing firms include following a growth-oriented mission and participating in interorganisational relationships. Rapidly growing firms create unique customer value by helping to maximise customer utility, reduce costs and/or uniquely increase organisational effectiveness. They emphasise training, employee development, financial incentives and stock options in their human resource management practices (Barringer et al., 2005).

When small firms grow rapidly, their product and market scope widens and organisational complexity increases (e.g., Moores and Yuen, 2001). Consequently, growing pains (Flamholtz and Randle, 2000) and tensions (Davila, 2005) arise, due to a lack of balance between informal, social control and formalisation of the control package (Covin and Slevin, 1989; Romano and Ratnatunga, 1994; Moores and Yuen, 2001). Researchers point to a palette of different explanations underlying the gradual increase in weight of formal components. Already the desire to grow tends to mean that firms use more information (Lybaert, 1998). They may at this stage experience a higher marginal return on the associated investments (Howorth and Westhead, 2003) as their future-oriented decision making needs to be based on a greater amount of information, and oriented to a greater number of solutions (Driver and Mock, 1975). In addition to size, Davila (2005) relates this tendency to age (learning is codified into formal systems) replacement of the original founder, industry and strategy. Others point to the role of external pressures. Increasing pressures for formalisation may originate with external sources of financing (Granlund and Taipaleenmäki, 2005) or supply chains (Hopper et al., 1999). The timing of adoption of formal controls may also coincide with contingent events including a cash flow crisis, shortage of funding or innovation development (Reid and Smith, 2000).

In their longitudinal study, Cardinal et al. (2004) find that the development of management control systems in an entrepreneurial firm evolves according to a balance-imbalance-rebalance pattern. The drivers of this pattern are imbalance during crises, and performance problems that trigger radical shifts in control. When the shifts are not carefully crafted, the result is a pendulum effect, leading to additional imbalance due to excessive reliance on formal or informal controls. Competency traps (Levitt and March, 1988) also appear to influence (hinder) control system development, and previously used controls remain in layers despite surface level changes. In a related fashion, Perren and Grant (2000) suggest that owner-managers develop idiosyncratic accounting practices and have considerable latitude in determining whether formal controls enter the firm, and if so, how such models will be interpreted and used in the local context. 
Hambrick and Crozier (1985) identify four fundamental challenges that confront rapid-growing firms; instant size, a sense of infallibility, internal turmoil and extraordinary resource needs. When sales grow rapidly, the challenge of instant size becomes apparent as firms build up staff and hire specialised personnel (Doutriaux, 1984; Blau and Schoenherr, 1971; Fombrun and Wally, 1989) often with a willingness to take risks (Gupta and Govindarajan, 1984) and technical skills. Problems of employee disaffection and disorientation occur as the cohesion and sense of family in the small firm disappears. New staff managers enter and may not comply with the approaches of original managers, accustomed to collegial, face-to-face problem solving among 'family members' (cf. Cooper et al., 1994). New responsibilities emerge that may not fit with the capabilities available in the firm, and specific knowledge becomes needed to manage the new roles. Gaining expertise in functional positions helps the firm to offer more innovative products (Kazanjian and Drazin, 1990) and to engage in more formal planning (Olson and Bokor, 1995) while simultaneously creating considerable demands for control, enabled by improved communication both vertically and horizontally (Galbraith, 1973).

A sense of infallibility occurs when the favourable development of rapidly growing firms make them rigidly convinced of the excellence of their strategies and behaviours although the environment is turbulent and changing (Hedberg and Jönsson, 1978). Internal turmoil can result from a substantial influx of new employees and a rapidly magnifying amount of information to process and number of decisions to make. When rapid sales growth is associated with a widened range of products and markets, the need for horizontal differentiation ${ }^{6}$ arises and the greater the diversity of products, the more control problems will arise (Williamson, 1970; Galbraith, 1973).

Although firms may be profitable, their growing requirements to finance expanding operations can result in cash shortages that put a strain on employees and managers and negatively affect the quality of decisions. The task of attracting resources to small firms is perhaps the greatest of challenges, as resource providers are likely to consider the lack of reputation and record of accomplishment a risk factor (Brush et al., 2001; Bamford et al., 2000; Cooper et al., 1994). When growing firms face the need for greater working capital they may turn to public venues and broaden their ownership basis. If additional owners are attracted, shareholders may demand formal controls to monitor the contractual fulfilments of managers (Jensen and Meckling, 1976). Institutional theorists repeatedly find evidence suggesting that formal accounting and control are used to project an image of rational practice towards the environment, to maintain support needed for firm survival (Berry et al, 1985; Covaleski and Dirsmith, 1988; Nahapiet, 1988; Covaleski et al., 1993). For small firms that struggle to finance their growth and to obtain resources, formal management controls are likely to be an important part of being taken seriously by external parties (Stone, 1989; Stone and Brush, 1996; Lounsbury and Glynn, 2001).

To summarise, balance for small firms that grow rapidly is likely to equal a motion where the owner-manager can sense the growth of the firm like a pilot sensing the Gforce during take-off. During such evolution, antithetical balance (Sutcliffe et al., 2000) between formal and informal control package components is risky and can result in a backlash. An intense and widely shared commitment to growth can create groupthink (Janis, 1972), which must be balanced through components of the control package (Hedberg and Jönsson, 1978). At the same time, the weight of formal components will increase. It would seem that the dynamics of rapid growth imply that viewing balance as 
an act may be fruitful. The owner-manager has tensions to balance during growth, which relate to imbalance (as a state) in the control package.

\subsection{Attributes of environmental turbulence}

It is almost an axiom in management studies that successful businesses align their strategies and structures to the environments in which they operate ${ }^{7}$. Siggelkow and Rivkin (2005) note that environmental change is dealt with under several labels in the literature, including dynamism (Mintzberg, 1979), velocity (Eisenhardt, 1989) and uncertainty (Galbraith, 1973). They define an environment as turbulent if the mapping from firm actions to performance outcomes changes frequently, profoundly and in ways that are difficult to predict, due to changes in demand, competition, technology or regulation (see also Eisenhardt and Bourgeouis, 1988).

It is conceivable that the attributes of small firms make them better equipped than their larger counterparts to respond to environmental turbulence (e.g., Fiegenbaum and Karnani, 1991; Hitt and Ireland, 1985; Power and Reid, 2005). Turbulence may even encourage managers of small firms to be alert to and explore new opportunities that arise in such an environment (Préfontaine and Bourgault, 2002). Empirical results however do not conclusively support the superiority of small firms to handle turbulence (e.g., Westhead et al., 2004). One likely reason is that small firms are vulnerable and thus sensitive to environmental changes (Merz and Sauber, 1995).

The attributes contributing to high performance among small firms in hostile ${ }^{8}$ and turbulent environments include an organic structure, an entrepreneurial strategic posture and a competitive profile characterised by a long-term, goal-oriented approach to management, high product/service-prices and a high degree of awareness about industry trends (Covin and Slevin, 1989; Merz and Sauber, 1995). The unpredictable changes associated with turbulence imply that there will be little manoeuvring time. In such conditions entrepreneurs must be action-oriented (Brunsson, 1982), relying on inspiration (Thompson, 1967) and beliefs about the future (Weick, 1995; Weick et al., 2005; see also Hedberg and Jönsson, 1978). At the same time, it may be useful to foster competing views on the mission of the firm (Häckner, 1993) to avoid a sense of infallibility (Hambrick and Crozier, 1985). Possibly, imbalances in the control package may act as the devil's advocate, making sure that important signals can break though the belief-driven logic (Hedberg and Jönsson, 1978). Contemporaneously, it would seem that balance is a matter not only of situational requirements but also time. Both rapid growth and environmental change imply a need to reconfigure the control package over time (e.g., Cardinal et al., 2004.

\section{Three contemporary frameworks for a balanced approach to management control}

This section examines the conceptions of balance underlying the balanced scorecard (e.g., Kaplan and Norton, 1992), the levers of control framework (Simons, 1995) and Otley's (1999) performance management framework, and relates that discussion to the generic features of balance in Section 2 above. 


\subsection{The balanced scorecard}

One fundamental principle behind the balanced scorecard is the idea that managers should direct balanced attention to different dimensions and develop measures that drive performance concerning each dimension (Kaplan and Norton, 1992). In its most widespread version, the balanced scorecard endorses four fundamental perspectives: the financial, the customer perspective, the internal perspective and an innovation/learning perspective. Kaplan and Norton (1996b, p.10) use the concept of balance to characterise the inclusion of external and internal measures, concerning outcomes and performance drivers, where the former are considered to be objective and the latter subjective. Balance refers to a desirable state where managers have access to '...complex information at a glance' [Kaplan and Norton, (1992), p.71], to guide the firm towards goal congruence (e.g., Anthony, 1965). The object of balance is the framework itself, with the perspectives as components and hypothetical, sequential, cause/effect-relationships between those. The notion of balance is synergistic (Sutcliffe et al., 2000) and encourages coherence between formal components. Although components encompass a lateral orientation along the value chain (cf. Otley et al., 1995), control is cybernetic (Beer, 1966) and occurs formally top-down (Norreklit, 2000), assuming that the company strategy is correctly formulated by management (Mouritsen et al., 1995, 1996).

\subsection{The levers of control framework}

The levers of control framework [Simons, (1995), p.4] is based on the assumption that it is necessary to balance tensions between opposing demands related to freedom and constraint, empowerment and accountability, top-down direction and bottom-up creativity, experimentation and efficiency. The framework consists of four levers of control: the diagnostic and interactive controls and the beliefs and boundary systems. Diagnostic controls monitor performance and correct deviations. Interactive controls are formal information systems managers use to be regularly and personally involved in decisions. A beliefs system is an explicit set of organisational definitions formally communicated by senior management. Boundary systems impose constraints on search activities by determining acceptable domains of activity. According to this framework, balance is a state where tensions are reconciled, by integration of the forces of the four levers of control [Simons, (1995), p.13). The object of balance is the framework itself, as a means of strategy implementation (ibid, p.10-11). The levers represent formal components, connected through a dynamic interplay (ibid, p.158f) where causation is mutual. Balance is synergistic (Sutcliffe et al., 2000) and includes formal components that may be socially oriented.

\subsection{The performance management framework}

Otley's (1999) performance management framework aspires to reach beyond the measurement of (financial) performance by means of a set of five questions for performance management. The questions proposed are the following: 
1 What are the key objectives that are central to the organisation's overall future success, and how does it go about evaluating its achievement for each of these objectives?

2 What strategies and plans has the organisation adopted, and what are the processes and activities required to implement these successfully? How does the organisation assess and measure the performance of these activities?

3 What level of performance does the organisation need to achieve in each of the areas defined in the above two questions, and how does to go about setting appropriate performance targets for them?

4 What rewards will managers (and other employees) gain by achieving these performance targets (or, conversely, what penalties will they suffer by failing to achieve them)?

5 What are the information flows (feedback and feed-forward loops) that are necessary to enable the organisation to learn from its experience, and to adapt its current behaviour in the light of that experience?

It is difficult to infer a specific conception of balance underlying Otley's (1999) framework. However, the framework suggests that its components are inter-connected (p.369) and that strengths in some areas can balance weaknesses in other areas (p.380). In addition, the framework suggests that circumstances will determine the suitability of any given configuration of components. This implies that balance refers to a desirable, synergistic (Sutcliffe et al., 2000) state concerning the control package itself, which depends on the mix and characteristics of the components therein. The performance management framework is formal and predominantly cybernetic (Beer, 1966). The sequential pattern of questions posed in the framework implies a top-down orientation.

\section{Synthesis}

The previous section reveals that the management control frameworks reviewed all treat balance as a desirable and synergistic state, where the management control framework is configured in a way that balances the content of the framework (Kaplan and Norton, 1992; Otley, 1999) or reconciles tensions associated with strategy implementation (Simons, 1995). In all cases, the basic design refers to a mix of interrelated and formal components. The relationships between the components differ, however. The performance management framework alludes to relationships but those are not explicit although the questions posed follow a sequential logic. The balanced scorecard considers relationships in terms of a sequential success formula, which differs from the mutual causality emphasised in the levers of control framework. The balanced scorecard appears to distribute weight equally whereas this seems to depend on the situation in the levers of control and the performance management frameworks. When it comes to coherence between components, this is a feature of all three frameworks, even if the levers of 
control framework recognise tensions. All frameworks address dynamics to some extent, even if the balanced scorecard and the performance management frameworks are predominantly cybernetic. See Table 1 for an overview).

The consistency between the conceptions and features of balance endorsed by these contemporary management control frameworks and the situational requirements of small, rapidly growing firms in turbulent environments is limited in several respects. Neither Kaplan and Norton (1992) nor Simons (1995) or Otley (1999) explicitly acknowledge the informal features of the control package of small firms (e.g., Perren and Grant, 2000; Collier, 2005). When it comes to the orientation of components, it would seem that all frameworks could accommodate both a vertical and a horizontal orientation. However, when it comes to using the frameworks, the social dimension is explicitly addressed only through Simons' (1995) interactive control.

Perhaps more importantly, the observation that all frameworks represent a conception of balance as a state is troublesome when related to the conditions of small, rapidly growing firms in turbulent environments. For such firms, the literature review in Section 3 indicates that it may often be the act of balancing which is the main challenge for firms in this category (e.g., Flamholtz and Randle, 2000). Although Simons (1995) does discuss balancing, the levers of control framework does treat balance as a state where tensions are reconciled. Rather, the literature review suggests that tensions are not reconciled though control (e.g., Hambrick and Crozier, 1985; Fombrun and Wally, 1989). Instead, control of small, rapidly growing firms seems to refer to a continuous act of balancing, which the owner-managers is forced to struggle with (Perren and Grant, 2000). This main object of this act is likely to be the emergence (e.g., Bird, 1992) and realisation (Covin and Slevin, 1989; Fombrun and Wally, 1989) of strategy, which may (or may not) include the contents of the control package at any given point in time.

In addition, all three management control frameworks consider the state of balance desirable. According to this logic, balance equals harmony (Cardinal et al., 2004) or at least the reconciliation of tension (Simons, 1995), which allows the firm to manoeuvre in alignment towards goal fulfilment. However, the literature review in Section 3 clearly suggests that balance may not always be desirable (e.g., Häckner, 1993). In particular, some degree of imbalance may be fruitful in conditions of environmental turbulence. This kind of imbalance may protect the firm from groupthink (Janis, 1972) or a sense of infallibility (Hambrick and Crozier, 1985), by questioning assumptions and detecting environmental signals that disconfirm the current strategies and behaviours or call them into doubt (cf. Hedberg and Jönsson, 1978).

Moreover, while all frameworks recognise the need to adapt the control package to situational requirements, the literature review in Section 3 suggests that a temporal dimension should supplement this situational perspective. Small firms that grow rapidly in turbulent conditions are in continuous motion (e.g., Moores and Yuen, 2001; Davila, 2005). Thus, it is not only the configuration of the control package at any given point in time, which relates to balance. Balance also refers to the need to reconfigure the control package over time, to keep up with the dynamics of firm evolution (e.g., Cardinal et al, 2004). 
Table 1 An overview of characteristics and balance features of the balanced scorecard, the levers of control framework and the performance management framework

\begin{tabular}{|c|c|c|c|}
\hline $\begin{array}{l}\text { Characteristics of the } \\
\text { management control } \\
\text { package }\end{array}$ & $\begin{array}{l}\text { The balanced } \\
\text { scorecard }\end{array}$ & $\begin{array}{l}\text { The levers of control } \\
\text { framework }\end{array}$ & $\begin{array}{c}\text { The performance } \\
\text { management } \\
\text { framework }\end{array}$ \\
\hline Basic assumption & $\begin{array}{l}\text { Managers need } \\
\text { multidimensional } \\
\text { information for } \\
\text { decision making }\end{array}$ & $\begin{array}{l}\text { Managers need to } \\
\text { balance tensions } \\
\text { between freedom and } \\
\text { constraint, } \\
\text { empowerment and } \\
\text { accountability, } \\
\text { direction and } \\
\text { creativity, } \\
\text { experimentation and } \\
\text { efficiency }\end{array}$ & $\begin{array}{l}\text { Managers need to } \\
\text { manage performance } \\
\text { through overall } \\
\text { control by constantly } \\
\text { addressing five } \\
\text { enduring questions }\end{array}$ \\
\hline $\begin{array}{l}\text { Main control } \\
\text { principle }\end{array}$ & Cybernetic, top-down & Dynamic & $\begin{array}{l}\text { Cybernetic, } \\
\text { top-down }\end{array}$ \\
\hline Basic design & $\begin{array}{l}\text { Formal and } \\
\text { interlinked objectives } \\
\text { and measures in four } \\
\text { dimensions }\end{array}$ & $\begin{array}{l}\text { Four formal and } \\
\text { interlinked levers of } \\
\text { control }\end{array}$ & $\begin{array}{l}\text { Five formal and } \\
\text { interlinked areas } \\
\text { posed as questions }\end{array}$ \\
\hline $\begin{array}{l}\text { Conception of } \\
\text { balance }\end{array}$ & $\begin{array}{l}\text { A desirable, } \\
\text { synergistic state of } \\
\text { access to 'complex } \\
\text { information at a } \\
\text { glance' }\end{array}$ & $\begin{array}{l}\text { A desirable, } \\
\text { synergistic state } \\
\text { where tensions are } \\
\text { reconciled }\end{array}$ & $\begin{array}{l}\text { A desirable, } \\
\text { synergistic state } \\
\text { where weaknesses in } \\
\text { some areas are } \\
\text { balanced by strengths } \\
\text { elsewhere }\end{array}$ \\
\hline Object of balance & $\begin{array}{l}\text { The basic design of } \\
\text { the control package }\end{array}$ & $\begin{array}{l}\text { The basic design of } \\
\text { the control package }\end{array}$ & $\begin{array}{l}\text { The basic design of } \\
\text { the control package }\end{array}$ \\
\hline $\begin{array}{l}\text { Attention to } \\
\text { dynamics }\end{array}$ & $\begin{array}{l}\text { Yes, through } \\
\text { innovation/learning } \\
\text { perspective }\end{array}$ & $\begin{array}{l}\text { Yes, through } \\
\text { integration of levers } \\
\text { in general and } \\
\text { interactive control in } \\
\text { particular }\end{array}$ & $\begin{array}{l}\text { Yes, through } \\
\text { feedback and } \\
\text { feed-forward } \\
\text { information flows }\end{array}$ \\
\hline \multicolumn{4}{|l|}{ Features of balance } \\
\hline Mix of components & $\begin{array}{l}\text { Financial, customer, } \\
\text { internal, and } \\
\text { innovation/learning } \\
\text { perspectives }\end{array}$ & $\begin{array}{l}\text { Diagnostic controls, } \\
\text { interactive controls, } \\
\text { beliefs systems and } \\
\text { boundary systems }\end{array}$ & $\begin{array}{l}\text { Key objectives, } \\
\text { strategies and plans, } \\
\text { performance levels } \\
\text { and targets, rewards } \\
\text { and information } \\
\text { flows (feedback and } \\
\text { feed-forward) }\end{array}$ \\
\hline $\begin{array}{l}\text { Weight of } \\
\text { components }\end{array}$ & Equal & Adapted to situation & Adapted to situation \\
\hline $\begin{array}{l}\text { Connections between } \\
\text { components }\end{array}$ & $\begin{array}{l}\text { Hypothetical, } \\
\text { sequential } \\
\text { cause/effect- } \\
\text { relationships } \\
\text { representing strategy }\end{array}$ & $\begin{array}{l}\text { Dynamic interplay } \\
\text { between levers } \\
\text { (mutual causality) }\end{array}$ & $\begin{array}{l}\text { Yes, sequential, but } \\
\text { not presented } \\
\text { explicitly }\end{array}$ \\
\hline $\begin{array}{l}\text { Coherence between } \\
\text { components }(\mathrm{Y} / \mathrm{N})\end{array}$ & $\mathrm{Y}$ & $\mathrm{Y}$ & $\mathrm{Y}$ \\
\hline
\end{tabular}




\section{Conclusions and future directions}

Admittedly, the control packages of small firms that grow rapidly in turbulent environments need a stable orientation towards profitability and cash flow. However, this paper argues that there is a need for a rich and dynamic conception of balance as a basis for future research on the management control package of such firms. The results of this paper tentatively suggest that the dynamics of balance should include considering balance as a state and as an act, acknowledging requirements of balance and imbalance and taking situational as and temporal dimensions into account. These suggestions are summarised in Table 2.

Table 2 A tentative conception of balance for the management control package of small, rapidly growing firms in turbulent environments

\begin{tabular}{lll}
\hline Conception of balance & \multicolumn{1}{c}{ State } & \multicolumn{1}{c}{ Act } \\
\hline & $\begin{array}{l}\text { Balance refers to the } \\
\text { configuration of the control } \\
\text { package in terms of } \\
\text { situational requirements on } \\
\text { components, relations, weight } \\
\text { and coherence }\end{array}$ & $\begin{array}{l}\text { Balance refers to the act of } \\
\text { balancing tensions associated } \\
\text { with the emergence and } \\
\text { realisation of strategy, given } \\
\text { the attributes and dynamics of } \\
\text { small, rapidly growing firms } \\
\text { in turbulent environments }\end{array}$ \\
\hline Dual causality requirements & \multicolumn{1}{c}{ Balance } & \multicolumn{1}{c}{ Imbalance } \\
\hline & $\begin{array}{l}\text { Components are mutually } \\
\text { reinforcing in that each } \\
\text { facilitates and contributes to } \\
\text { the others }\end{array}$ & $\begin{array}{l}\text { Components are divergent in } \\
\text { that one or some create(s) } \\
\text { tension in relation to the } \\
\text { others }\end{array}$ \\
\hline Conception of space and time & \multicolumn{1}{c}{$\begin{array}{c}\text { Situational (space) } \\
\text { Balance refers to the } \\
\text { suitability and adequacy of } \\
\text { the configuration (state) of } \\
\text { the control package in } \\
\text { relation to situational } \\
\text { requirements }\end{array}$} & $\begin{array}{l}\text { Balance refers to the capacity } \\
\text { to modify and alter the } \\
\text { control package in response } \\
\text { to the evolution of the firm } \\
\text { and its environment }\end{array}$ \\
\hline
\end{tabular}

While the literature often treats balance as a harmonious condition, it would seem that balance is as much a matter of an act as of a desirable state. When there are tensions between components of the control package, owner-managers of small firms that grow rapidly in turbulent environments cannot count on their ability to reconcile them. Rather it may be necessary to balance tensions using components that are related but incoherent, yet necessary for survival and growth. For example, this is likely to be the case when requirements from the external environment concerning the contents of the control package do not fit with belief-driven, social control practices.

Similarly, although a state of balance is a theoretically appealing ideal, small, rapidly growing firms in turbulent conditions often may find themselves in a state of imbalance. Given the nature of the conditions under which such firms operate, some degree of imbalance may even be a useful feature of their management control package. Small firms are vulnerable and dominated by an informal logic. When they grow rapidly, they face numerous tensions. If this occurs in a turbulent environment, changes are frequent, profound and unpredictable. It is necessary for such firms to quickly detect and respond 
to new developments. Some degree of imbalance can be helpful in continuous questioning of the current strategy and the associated behaviours. In a state of harmonious balance, there is little tension and important signals may go undetected.

There is also a situational as well as a temporal dimension to the dynamics of balance. While this paper is specifically concerned with the situational requirements of small, rapidly growing firms in turbulent environments in relation to the control package, the literature review reveals the necessity of adding a temporal dimension to the analysis (see for example Burns and Baldvinsdottir, 2005). One reason why this is the case is that the act of balancing tensions is a process that takes place over time. Another reason is that the situational requirements of the firms of interest here are by definition such that changes in conditions take place continuously. Extensive imbalances between the control package and the situational requirements are likely to trigger control package changes. Such changes may concern the mix or weight of components, as well as the relations and coherence between them. Ideally, sensitising mechanisms in the firm assist in detecting such needs.

The contribution of the present paper lies in the right-hand side of Table 2, offering a wider conception of balance than that of the current literature. As pinpointed by Perren and Grant (2000), existing research findings contradict each other, as some imply that small firms use little information, have poor control and make ad-hoc decisions, while others claim that control can be effective through informal means. The conceptual proposition advanced here helps to make sense of this paradox by suggesting that there are several facets of balance to consider in relation to the control packages of small, rapidly growing firms in turbulent environments. Given the dynamics associated with these additions, it would seem that empirical research to test, refine and specify these suggestions should predominantly rely on longitudinal research designs.

\section{Acknowledgements}

The author would like to express his gratitude to Professors Einar Häckner, Fred A. Jacobs and Sten Jönsson for their insightful comments to previous versions of this paper.

\section{References}

Alvarez, S.A. and Barney, J.B. (2002) 'Wasps and tarantulas: alliances between entrepreneurial firms and large firms', working paper, Fisher College of Business, Ohio State University.

Alvesson, M. and Kärreman, D. (2004) 'Interfaces of control: technocratic and socio-ideological control in a global management consultancy firm', Accounting, Organizations \& Society, Vol. 29, Nos. 3/4, pp.23-45.

Anthony, R.W. (1965) 'Planning and control systems: a framework for analysis', Management Studies, Vol. 19, No. 1, pp.29-44.

Argyris, C. and Schon, D. (1977) 'Organizational learning and management information systems', Accounting, Organizations and Society, Vol. 2, No. 2, pp.113-123.

Argyris, C. and Schon, D. (1996) Organizational Learning, Addison-Wesley, Reading, MA.

Bamford, C.E., Dean, T.J. and MacDougall, P.P. (2000) 'An examination of the impact of initial founding conditions and decisions upon the performance of new bank start-ups', Journal of Business Venturing, Vol. 15, pp.253-277. 
Barker, J. (1993) 'Tightening the iron cage: concertive control in self managing teams', Administrative Science Quarterly, Vol. 38, pp.408-437.

Barringer, B.R., Joanes, F.F. and Neubaum, D.O. (2005) 'A quantitative content analysis of the characteristics of rapid-growth firms and their founders', Journal of Business Venturing, Vol. 20, pp.663-687.

Beer, S. (1966) Decision and Control: the Meaning of Operational Control and Management Cybernetics, Wiley, London.

Berry, A.J., Capps, T., Cooper, D., Ferguson, D., Hopper, T. and Lowe, E.A. (1985) 'Management control in an area of the NCB: rationales of accounting practices in a public enterprise', Accounting, Organizations \& Society, Vol. 10, No. 1, pp.3-28.

Bird, B.J. (1992) 'The operation of intentions in time: the emergence of a new venture', Entrepreneurship Theory \& Practice, Vol. 17, No. 1, pp.11-20.

Blau, P.M. and Shoenherr, R.A. (1971) The Structure of Organizations, Basic Books, New York.

Boland, R. (1979) 'Control causality and information systems requirements', Accounting, Organizations and Society, Vol. 4, No. 4, pp.259-272.

Bouwens, J. and Abernethy, M.A. (2000) 'The consequences of customization on management accounting system design', Accounting, Organizations \& Society, Vol. 25, No. 3, pp.221-241.

Bradach, J.L. and Eccles, R.G. (1989) 'Price, authority and trust: from ideal types to plural forms', Annual Review of Sociology, Vol. 15, pp.97-118.

Brownell, P. (1987) 'The use of accounting in management control', in: K. Ferris and J. Livingstone (Eds.): Management Planning and Control: The Behavioral Foundations, pp.177-196, Century VII, Beavercreek, Ohio.

Brüdel, J., Preisendörfer, P. and Ziegler, R. (1992) 'Survival chances of newly founded organizations', American Sociological Review, Vol. 57, No. 2, pp.227-242.

Brunsson, N. (1982) 'The irrationality of action and action rationality: decisions, ideologies and organizational actions', Journal of Management Studies, Vol. 19, No. 1, pp.29-44.

Brush, C.G., Greene, P. and Hart, M.M. (2001) 'From initial idea to unique advantage: the entrepreneurial challenge of creating a resource base', Academy of Management Executive, Vol. 15, pp.64-81.

Buick, I., Halcro, K. and Lynch, P. (1998) 'Scottish hospitality enterprises and their networks', Paper presented at the International Council for Small Business Conference, June, Singapore.

Burchell, S., Clubb, C., Hopwood, A. and Hughes, J. (1980) 'The roles of accounting in organizations and society', Accounting, Organizations and Society, Vol. 5, No. 1, pp.5-27.

Burns, J. and Baldvinsdottir, G. (2005) 'An institutional perspective of accountants' new roles - the interplay of contradictions and praxis', European Accounting Review, Vol. 14, No. 4, pp.725-757.

Burns, T. and Stalker, G.M. (1961) The Management of Innovation, Tavistock, London.

Calof, J.L. (1993) 'The impact of size on internationalization', Journal of Small Business Management, Vol. 31, No. 4, pp.60-69.

Calori, R., Melin, L., Atamer, T. and Gustavsson, P. (2000) 'Innovative international strategies', Journal of World Business, Vol. 35, No. 4, pp.333-355.

Cardinal, L.B., Sitkin, S.B. and Long, C.P. (2004) 'Balancing and rebalancing in the creation and evolution of organizational control', Organization Science, Vol. 15, No. 4, pp.411-431.

Chapman, C.S. (1998) 'Accountants in organizational networks', Accounting, Organizations and Society, Vol. 23, No. 8, pp.737-766.

Chenhall, R.H. (2005) 'Integrative performance measurement systems, strategic alignment of manufacturing, learning and strategic outcomes: an exploratory study', Accounting, Organizations and Society, Vol. 30, No. 5, pp.395-422.

Chung, R.K. (1994) 'The horizontal organization: breaking down functional silos', Business Credit, Vol. 96, No. 5, pp.21-24. 
Collier, P.M. (2005) 'Entrepreneurial control and the construction of a relevant accounting', Management Accounting Research, Vol. 16, pp.321-339.

Cooper, A.C., Gimeno-Gascon, F.J. and Woo, C.Y. (1994) 'Initial human and financial capital as predictors of new venture performance', Journal of Business Venturing, Vol. 9, No. 5, pp.371-396.

Covaleski, M.A. and Dirsmith, M.W. (1988) 'An institutional perspective on the rise, social transformation and fall of a university budget category', Administrative Science Quarterly, Vol. 33, pp.562-587.

Covaleski, M.A., Dirsmith, M.W. and Michelman, J.E. (1993) 'An institutional theory perspective on the DRG framework case-mix accounting systems and health-care organizations', Accounting, Organizations and Society, Vol. 18, No. 1, pp.65-80.

Covin, J.G. and Slevin, D.P. (1989) 'Strategic management of small firms in hostile and benign environments', Strategic Management Journal, Vol. 10, No. 1, pp.75-87.

Daft, R.L. (1982) 'Bureaucratic vs. nonbureaucratic structure and the process of innovation and change; in: S. Bacharach (Ed.): Research in the Sociology of Organizations, Vol. 1, pp.129-166, JAI, Greenwich, CT.

Daft, R.L. and Macintosh, N.B. (1981) 'A tentative exploration into the amount and equivocality of information processing in organizational work units', Administrative Science Quarterly, Vol. 26, pp.207-224.

Dana, L.P. (1998) 'Small but not independent: SMEs in Japan', Journal of Small Business Management, Vol. 36, No. 4, pp.73-76.

Davig, W. and Brown, S. (1992) 'Incremental decision making in small manufacturing firms', Journal of Small Business Management, April.

Davila, T. (2005) 'An exploratory study on the emergence of management control systems: formalizing human resources in small growing firms', Accounting, Organizations and Society, Vol. 30, pp.223-248.

Dent, J.F. (1987) 'Tension in the design of formal control systems: a field study in a computer company', in: W.J. Burns and R.S. Kaplan (Eds.): Accounting and Management: Field Study Perspectives, pp.119-145, Harvard Business School Press, Boston.

Dent, J.F. (1996) 'Global competition: challenges for management accounting and control', Management Accounting Research, Vol. 7, pp.247-269.

Desouza, K.C. and Awuzu, Y. (2006) 'Engaging tensions of knowledge management control', Singapore Management Review, Vol. 28, No. 1, pp.1-13.

Doutriaux, J. (1984) 'Evolution of the characteristics of (high tech) entrepreneurial firms', in J.A. Hornaday, F.A. Tardley Jr, J.A. Timmons and K.H. Vesper (Eds.): Frontiers of Entrepreneurship Research, pp.368-386, Babson College Center for Entrepreneurial Studies, Wellesley, MA.

Driver, M.J. and Mock, J. (1975) 'Human information processing, decision style theory, and accounting information systems', The Accounting Review, Vol. 50, pp.490-508.

Earl, M.J. and Hopwood, A.G. (1980) 'From management information to information management', in H.C.J. Lucas (Ed.): The Information Systems Environment, pp.3-13, North Holland, Amsterdam.

Eisenhardt, K.M. (1989) 'Making fast strategic decisions in high-velocity environments', Academy of Management Journal, Vol. 32, No. 3, pp.547-546.

Eisenhardt, K.M. and Bourgeouis, L.J. (1988) 'Politics of strategic decision making in high-velocity environments: towards a midrange theory', Academy of Management Journal, Vol. 32, pp.543-576.

Ekanem, I. and Smallbone, D. (2007) 'Learning in small manufacturing firms: the case of investment decision-making behaviour', International Small Business Journal, Vol. 25, pp.107-128. 
Evans, D.F. (1999) 'Japanese SMEs and independence: a different view', Journal of Small Business Management, Vol. 37, No. 4, pp.67-72.

Ewing, P. and Samuelsson, L. (1998) Styrning med balans och fokus [Control with Balance and Focus], Liber Ekonomi, Stockholm.

Feeser, H.R. and Willard, G.E. (1989) 'Incubators and performance: a comparison of high- and low-growth high-tech firms', Journal of Business Venturing, Vol. 4, pp.429-442.

Feindt, S., Jeffcoate, J. and Chappell, C. (2002) 'Identifying success factors for rapid growth in SME e-commerce', Small Business Economics, Vol. 19, pp.51-62.

Ferner, A. (2000) 'The underpinnings of bureaucratic control systems: HRM in European multinationals', Journal of Management Studies, Vol. 37, No. 4, pp.521-540.

Ferreira, A. and Otley, D. (2005) 'The design and use of management control systems: an extended framework for analysis', AAA 2006 Management Accounting Section (MAS) Meeting, available at SSRN: http://ssrn.com/abstract $=682984$.

Fiegenbaum, A. and Karnani, A. (1991) 'Output flexibility - a comparative advantage for small firms’, Strategic Management Journal, Vol. 12, pp.101-114.

Flamholtz, E. and Randle, Y. (2000) Growing Pains: Transitioning from an Entrepreneurship to a Professionally Managed Firm, Jossey-Bass, San Francisco, CA.

Fombrun, C.J. and Wally, S. (1989) 'Structuring small firms for rapid growth', Journal of Business Venturing, Vol. 4, pp.107-121.

Freeman, J., Carroll, G.R. and Hannan, M.T. (1983) 'The liability of newness: age dependence in organizational death rates', American Sociological Review, Vol. 48, pp.692-710.

Frow, N., Marginson, D. and Ogden, S. (2005) 'Encouraging strategic behaviour while maintaining management control: multi-functional project teams, budgets, and the negotiation of shared accountabilities in contemporary enterprises', Management Accounting Research, Vol. 16, pp.269-292.

Galbraith, J.R. (1973) Designing Complex Organizations, Addison-Wesley, Reading, MA.

Galbraith, J.R. (1977) Organization Design, Addison-Wesley, Reading, MA.

Geary, J.F and Dobbins, A. (2001) 'Teamworking: a new dynamic in the pursuit of management control', Human Resource Management Journal, Vol. 11, No. 1, pp.3-24.

Gilbert, B.A., MacDougall, P. and Audretsch, D.B. (2006) 'New venture growth: a review and extension', Journal of Management, Vol. 32, pp.926-950.

Granlund, M. and Taipaleenmäki, J. (2005) 'Management control and controllership in new economy firms - a life cycle perspective', Management Accounting Research, Vol. 16, pp.21-57.

Gupta, A.K. and Govindarajan, V. (1984) 'Business unit strategy, managerial characteristics, and business unit effectiveness at strategy implementation', Academy of Management Journal, Vol. 27, pp.25-41.

Häckner, E. (1993) 'Conformity or divergence in describing the business concept and profitability', Scandinavian Journal of Management, Vol. 9, No. 4, pp.265-282.

Häckner, E. and Nilsson, A. (1999) 'Accounting information systems in SMEs', Journal of Enterprising Culture, Vol. 7, No. 19, pp.37-64.

Hambrick, D.C. and Crozier, L.M. (1985) 'Stumblers and stars in the management of rapid growth', Journal of Business Venturing, Vol. 1, pp.31-45.

Hambrick, D.C., Geletkanycz, A. and Fredrickson, J.W. (1993) 'Top executive commitment to the status quo: a test of some of its determinants', Strategic Management Journal, Vol. 17, No. 6, pp.401-418.

Hedberg, B. and Jönsson, S. (1978) 'Designing semi-confusing information systems for organizations in changing environments', Accounting, Organizations and Society, Vol. 3, No. 1, pp.47-64.

Hitt, M.A. and Ireland, R.D. (1985) 'Corporate distinctive competence, strategy, industry, and performance’, Strategic Management Journal, Vol. 6, pp.273-293. 
Hopper, T., Koga, T. and Goto, J. (1999) 'Cost accounting in small and medium sized Japanese companies: an exploratory study', Accounting and Business Research, Vol. 30, No. 1, pp.73-86.

Howorth, C. and Westhead, P. (2003) 'The focus of working capital management in UK small firms', Management Accounting Research, Vol. 14, pp.94-111.

Human, S.E. and Provan, K.G. (1996) 'External resource exchange and perceptions of competitiveness within organizational networks: an organizational learning perspective', Frontiers for Entrepreneurship Research, Vol. 45, No. 2, pp.327-369.

Indre, M. and Mark, E. (2006) 'Dynamics of social capital and their performance implications', Administrative Science Quarterly, Vol. 51, No. 2, pp.262-292.

Janis, I.L. (1972) Victims of Groupthink, Houghton Mifflin, Boston.

Jensen, M.C. and Meckling, W.H. (1976) 'Theory of the firm: managerial behaviour, agency costs and ownership structure', Journal of Financial Economics, Vol. 3, pp.305-360.

Jönsson, S. (1992) 'Accounting for improvement: action research on local management support', Accounting, Management \& Information Technology, Vol. 2, No. 2, pp.99-115.

Jönsson, S. (1996) 'Decoupling hierarchy and accountability: an examination of trust and reputation', in R. Munro and L. Mouritsen (Eds.): Accountability: Power, Ethos and the Technologies of Managing, pp.103-117, Thompson International Business Press, London.

Kaldor, N. (1972) 'The irrelevance of equilibrium economics', The Economic Journal, Vol. 82, No. 328, pp.1237-1255.

Kaplan, R.S. and Norton, D.P. (1992) 'The balanced scorecard: measures that drive performance', Harvard Business Review, Jan/Feb., pp.71-79.

Kaplan, R.S. and Norton, P. (1996a) 'Linking the balanced scorecard to strategy', California Management Review, Vol. 39, No. 1, pp.53-79.

Kaplan, R.S. and Norton, D.P. (1996b) The Balanced Scorecard: Translating Strategy into Action, Harvard Business School Press, Boston, MA.

Kaplan, R.S. and Norton, D.P. (2001a) 'Transforming the balanced scorecard from performance measurement to strategic management: part 1', Accounting Horizons, Vol. 15, No. 1, pp.87-104.

Kaplan, R.S. and Norton, D.P. (2001b) 'Transforming the balanced scorecard from performance measurement to strategic management: part II', Accounting Horizons, Vol. 15, No. 2, pp.147-160.

Kaplan, R.S. and Norton, D.P. (2007) 'Using the balanced scorecard as a strategic management system', Harvard Business Review, Vol. 85, Nos. 7/8, pp.150-161.

Kazanjian, R.K. and Drazin, R. (1990) 'A stage-contingent model of design and growth for technology based new ventures', Journal of Business Venturing, Vol. 5, pp.137-150.

Kirsch, L.J., Sambamurthy, V., Ko, D-G. and Purvis, R.L. (2002) 'Controlling information system development projects: the view from the client', Management Science, Vol. 48, No. 4, pp.484-498.

Kohn, T.O. (1997) ‘Small firms as international players', Small Business Economics, Vol. 9, No. 1, pp.45-51.

Kolb, D.A. (1984) Experiential Learning: Experience as the Source of Learning and Development, Prentice Hall, Englewood Cliffs, New Jersey.

Lawrence, P.R. and Lorsch, J.W. (1967) 'Differentiation and integration in complex organizations', Administrative Science Quarterly, Vol. 12, No. 1, pp.1-47.

Levitt, B. and March, J.G. (1988) 'Organizational learning', in W.R. Scott (Ed.): Annual Review of Sociology, Vol. 14, pp.319-340, JAI Press, Greenwich, CT.

Llewellyn, S. and Northcott, D. (2005) 'The average hospital', Accounting, Organizations and Society, Vol. 30, No. 6, pp. 555-583. 
Lindkvist, L. and Llewellyn, S. (2003) 'Accountability, responsibility and organization', Scandinavian Journal of Management, Vol. 19, pp.251-273.

Lounsbury, M. and Glynn, M.A. (2001) 'Cultural entrepreneurship: stories, legitimacy, and the acquisition of resources', Strategic Management Journal, Vol. 22, pp.545-564.

Lybaert, N. (1998) 'The information use in a SME: its importance and some elements of influence', Small Business Economics, Vol. 10, No. 2, pp.171-191.

Lynch, R.L. and Cross, K.F. (1991) Measure Up! Yardsticks for Continuous Improvements, Blackwell, Oxford.

March, J.G. (1988) The Pursuit of Organizational Intelligence, Blackwell Business, Malden, MA.

Merchant, K.A. and Van der Stede, W. (2007) Management Control Systems: Performance Meaurement, Evaluation and Incentives, 2nd ed, Prentice Hall, Harlow, UK.

Merz, G.R. and Sauber, M.H. (1995) 'Profiles of managerial activities in small firms', Strategic Management Journal, Vol. 16, No. 7, pp.551-564.

Miller, D. and Friesen, P.H. (1984) 'A longitudinal study of the corporate life cycle', Management Science, Vol. 30, No. 10, pp.1161-1183.

Mintzberg, H. (1979) The Structuring of Organizations: a Synthesis of the Research, Prentice-Hall, Englewood Cliffs, NJ.

Moores, K. and Yuen, S. (2001) 'Management accounting systems and organizational configuration: a life-cycle perspective', Accounting, Organizations and Society, Vol. 26, pp.351-389.

Morris, M.H., Allen, J., Schindehutte, M and Avila, R. (2006) 'Balanced management control systems as a mechanism for achieving corporate entrepreneurship', Journal of Managerial Issues, Vol. 18, No. 4, pp.468-493.

Mouritsen, J., Hoholt, J. and Jorgensen, A.A.V. (1995/1996) 'De nye og de gamle ikke-finansielle nogletal', Okonomistyring og informatik, pp.387-409.

Munro, R. and Mouritsen, J. (1996) Accountability: Power, Ethos and the Technologies of Managing, Thompson International Business Press, London.

Nahapiet, J. (1988) 'The rhetoric and reality of an accounting change: a study of resource allocation', Accounting, Organizations \& Society, Vol. 13, No. 4, pp.333-358.

Nayak, A. and Greenfield, S. (1994) 'The use of management accounting information for managing micro businesses', in A. Hughes and D.J. Storey (Eds.): Finance and the Small Firm, Routledge, London.

Norreklit, H. (2000) 'The balance on the balanced scorecard-a critical analysis of some of its assumptions', Management Accounting Research, Vol. 11, No. 1, pp.65-88.

Norris, G. and O'Dwyer, B. (2004) 'Motivating socially responsive decision making: the operation of management controls in a socially responsive organization', The British Accounting Review, Vol. 36, pp.173-196.

Olson, P.D. and Bokor, D.W. (1995) 'Strategy process-content interaction: effects on growth performance in small, start-up firms', Journal of Small Business Management, pp.34-36.

Osborn, C.S. (1998) 'Systems for sustainable organizations: emergent strategies, interactive controls and semi-formal information', Journal of Management Studies, Vol. 35, No. 4, pp.481-510.

Otley, D. (1980) 'The contingency theory of management accounting: achievement and prognosis', Accounting, Organizations \& Society, Vol. 5, No. 4, pp.413-428.

Otley, D. (1999) 'Performance management: a framework for management control systems research', Management Accounting Research, Vol. 10, pp.363-382.

Otley, D., Broadbent, J. and Berry, A. (1995) 'Research in management control: an overview of its development', British Journal of Management, Vol. 6, pp.31-44.

Ouchi, W.G. (1979) 'A conceptual framework for the design of organizational control mechanisms', Management Science, Vol. 25, No. 9, pp.833-848. 
Pearson, J.N., Bracker, J.S. and White, R.E. (1990) 'Operations management activities of small, high growth electronics firms', Journal of Small Business Management, January.

Peel, M.J., Wilson, N. and Howorth, C.A. (2000) 'Late payment and credit management in the small firm sector: some empirical evidence', International Small Business Journal, Vol. 18, No. 2, pp.17-37.

Pelham, A.M. (1999) 'Influence of environment, strategy, and market orientation on performance in small manufacturing firms', Journal of Business Research, Vol. 45, pp.33-46.

Perren, L. and Grant, L. (2000) 'The evolution of management accounting routines in small businesses: a social construction perspective', Management Accounting Research, Vol. 11, pp.391-411.

Power, B. and Reid, G.C. (2005) 'Flexibility, firm-specific turbulence and the performance of the long-lived small firm', Review of Industrial Organization, Vol. 26, pp.415-443.

Pratten, C. (1991) The Competitiveness of Small Firms, Cambridge University Press, Cambridge.

Préfontaine, L. and Bourgault, M. (2002) 'Strategic analysis and export behaviour of SMEs', International Small Business Journal, Vol. 20, pp.123-138.

Reid, G.C. and Smith, J.A. (2000) 'The impact of contingencies on management accounting system development', Management Accounting Research, Vol. 11, pp.427-450.

Roberts, J. (1991) 'The possibilities of accountability', Accounting, Organizations and Society, Vol. 16, No. 4, pp.403-422.

Roberts, J. (1996) 'From discipline to dialogue: individualizing and socializing forms of accountability', in R. Munro and J. Mouritsen (Eds.): Accountability: Power, Ethos and the Technologies of Managing, pp.40-61, Thompson International Business Press, London.

Romano, C.A. and Ratnatunga, J. (1994) 'Growth stages of small manufacturing firms: the relationship with planning and control', British Accounting Review, Vol. 26, pp.173-195.

Sexton, D. and VanAuken, P. (1982) 'Prevalence of strategic planning in small business', Journal of Small Business Management, Vol. 20, No. 3, pp.20-26.

Shan, W. (1990) 'An empirical analysis of organizational strategies by entrepreneurial hightechnology firms', Strategic Management Journal, Vol. 11, No. 2, pp.129-139.

Siggelkow, N. and Rivkin, J.W. (2005) 'Speed and search: designing organizations for turbulence and complexity', Organization Science, Vol. 16, No. 2, pp.101-122.

Simon, H.A. (1960) The New Science of Management Decision, Harper \& Row, New York.

Simons, R. (1990) 'The role of management control systems in creating competitive advantage: new perspectives', Accounting, Organizations and Society, Vol. 15, Nos. 1/2, pp.127-143.

Simons, R. (1995) Levers of Control: How Managers Use Innovative Control Systems to Drive Strategic Renewal, Harvard Business School Press, Boston.

Stinchcombe, A.L. (1965) 'Social structure and organizations', in J.G. March (Ed.): Handbook of Organizations, pp.153-193, Rand McNally, Chicago.

Stone, M. (1989) 'Planning as strategy in nonprofit organizations: an exploratory study'; Nonprofit and Voluntary Sector Quarterly, Vol. 18, pp.297-315.

Stone, M. and Brush, C.G. (1996) 'Planning in ambiguous contexts: the dilemma of meeting needs for commitment and demands for legitimacy', Strategic Management Journal, Vol. 17, No. 8, pp.633-652.

Street, C.T and Cameron, A-F. (2007) 'External relationships and the small business: a review of small business alliance and network research', Journal of Small Business Management, Vol. 45, No. 2, pp.239-266.

Sutcliffe, K.M., Sitkin, S.B. and Browning, L.D. (2000) 'Tailoring process management to situational requirements: beyond the control and exploration dichotomy', in R. Cole and W.R. Scott (Eds.): The Quality Movement and Organization Theory, pp.315-330, Sage, Thousand Oaks, CA.

Thompson, J.D. (1967) Organizations in Action: Social Science Bases of Administrative Theory, MacGraw-Hill, New York. 
Vaivio, J. (2004) 'Mobilizing local knowledge with 'provocative' non-financial measures', European Accounting Review, Vol. 3, No. 1, pp.39-71.

Vinten, G. (1999) 'Corporate communications in small-and medium-sized enterprises', Industrial and Commercial Training, Vol. 31, No. 3, pp.112-119.

Weick, K.E. (1995) Sensemaking in Organizations, Sage, Thousand Oaks.

Weick, K.E., Sutcliffe, K.M and Obstfeld, D. (2005) 'Organizing and the process of sensemaking', Organization Science, Vol. 16, No. 4, pp.409-421.

Westhead, P., Wright, M. and Ucbasaran, D. (2004) 'Internationalization of private firms: environmental turbulence and organizational strategies and resources', Entrepreneurship \& Regional Development, pp.501-522.

Williamson, O.E. (1970) Corporate Control and Business Behavior, Prentice-Hall, Englewood Cliffs, NJ.

Yap, C.S., Thong, Y.L. and Raman, K.S. (1994) 'Effect of government incentives on computerization in small business', European Journal of Information Systems, Vol. 3, No. 3, pp.191-206.

Yu, T.F-L. (2001) 'Towards a capabilities perspective of the small firm', International Journal of Management Reviews, Vol. 3, No. 3, pp.185-197.

\section{Notes}

1 The balanced scorecard and it's evolution over time is described in several publications, including Kaplan and Norton (1996a, 1996b, 2001a, 2001b, 2007). This paper mainly uses the ideas exposed in their first journal article (Kaplan and Norton, 1992) and book (1996b) on the topic.

2 The levers of control and the performance management frameworks are selected for inclusion here because they both fit well with aspirations of the control package to approach control in an overall, comprehensive sense. Although it might be argued that the balanced scorecard is concerned with a subset of controls for the control package, it is included here because of its explicit endorsement of balance in relation to management control.

3 The social, horizontal dimension receives much interest also in several other research streams, including entrepreneurship (Indre and Mark, 2006) and human resource management (e.g., Geary and Dobbins, 2001).

4 Ideas along this theme have also inspired many others, including Ouchi (1979), Bouwens and Abernethy (2000) and Chenhall (2005). The scope of the present paper is however such that we concentrate primarily on findings that relate to the context of small firms.

5 Although Jönsson (1996) does not study small firms, it is conceivable that high levels of trust and intense social interaction will be characteristic features of many small, family-like, firms.

6 Differentiation concerns the segmentation of the organisation into subsystems, each of which develops particular attributes in relation to the requirements posed by its external environment [Lawrence and Lorsch, (1967), p 4].

7 One influential competing perspective is that of 'strategic choice'; according to which managers often have considerable latitude in decision making (e.g., Calori et al., 2000).

8 As noted in the introductory paragraph to this section, the conceptual apparatus for characterising 'difficult' environmental conditions differs in the literature. Covin and Slevin (1989) define hostile environments as characterised by 'precarious industry settings, intense competition, harsh, overwhelming business climates and the relative lack of exploitable opportunities (p.75). Although turbulent environments may be hostile or friendly, it is in this paper expected that conditions such as those described by Covin and Slevin (1989) will affect the relationship between firm actions and performance in ways that match the definition of environmental turbulence proposed by Siggelkow and Rivkin (2005). 